\title{
Infotaiment Sehat
}

\author{
Fathurozi \\ Staf Balai Penelitian dan Pengembangan Agama Semarang
}

\begin{abstract}
Beberapa waktu lalu, fatwa "infotainment" yang dikeluarkan oleh Majelis Ulama Indonesia (MUI) menuai kontroversi, antara yang menyambut baik dan yang mengatakannya sebagai urusan tidak penting yang diadakan-adakan. Dus, yang pasti, seperti dikatakan oleh raja infotaiment Ilham Bintang, fatwa MUI itu selaras dengan kode etik jurnalistik yang mewajibkan setiap pemberitaan media sedapat mungkin dan seharusnya bisa dijauhkan dari unsur kebohongan (Kidzib atau fitnah) dan pergunjingan (ghibah).
\end{abstract}

Fatwa MUI tidak menggenalisir keharaman semua infotaiment yang ada selama ini. Yang diharamkan, seperti ditegaskan oleh ketua Bidang Fatwa MUI, KH. Ma'ruf Amin bukan infotainmennya, tapi nilai negatif yang ada di dalamnya. Jadi bukan format yang dipermasalahkan, namun substansinya. Infotaiment yang mengandung unsure pergunjingan dan kebohongan malah disebut Menkominfo Tifatul Sembiring bukan sebagai bagian dari kegiatan jurnalistik. Jenis informasi seperti itu, kata Tifatul, hanyalah tayangan hiburan, tak ubahnya seperti pertunjukkan musik dan kuis-kuis berhadiah yang bertebaran di televisi.

Kata KH. Ma'ruf Amin, infotainment sekarang secara umum tak lebih berbahaya daripada pornografi. Sudah selayaknya infotainment harus bersih dari unsur pemberitaan aib orang lain dan perkara privat para pesohor artis yang tak layak didengar oleh masyarakat luas.

Media sebagai ruang inspirasi publik sudah selaiknyalah memperbaiki tayangantayangan murahan yang justru menyesaki beban psikologis massa yang sudah jenuh dengan aktivitas keseharian. Media akan menjadi vitamin bila ia bukan hanya sebagai tontonan, tetapi pula tuntunan. Infotainment yang hanya mengumbar berita-berita buruk (bad news) menjadi "good news" akan membuat kontemplasi meditatif umat Islam terganggu.

Mereka dituntut untuk memperbaiki diri, tapi pada saat bersamaan, media justru mendorong mereka untuk mengetahui sisi buruk saudaranya sendiri, melalui berita gosip yang belum tentu benar adanya dan berita lain yang sifatnya fitnah.

\section{Dosa besar}

Dalam sistem moral Islam, ghibah atau menggunjing aib orang disetarakan dengan zina. Dosanya bahkan dikatakan lebih besar daripada zina. Mengapa demikian? Karena dosa zina hanya ditanggung secara personal, sementara ghibah dosanya bisa menjalar kemana-kemana seperti api yang membakar sebuah pemukiman berhimpit. 
Pertobatan zina mungkin bisa langsung diterima karena hal itu hanya menyangkut soal hak-hak moral agama dari Allah SWT (haqqullah). Tapi ghibah tak akan diampuni selama korban saudara yang jadi sumber gunjingan tidak memaafkannya. Dalam ghibah, hak-hak sebagai sesame saudara harus dibebaskan terlebih dulu sebelum mendapatkan ampunan secara agama dari Allah. Karena itulah, dalam al-Qur'an (QS. Al-Hujurat: 12), Allah mengumpamakan ghibah dengan perbuatan keji memakan daging saudaranya yang sudah meninggal.

Bahaya fitnah juga tak kalah laten. al-Qur'an menyebut fitnah lebih kejam daripada pembunuhan (al-fitnah asyaddu min al-qatl). Korban kejahatan pembunuhan mungkin hanya musuh yang dibenci, tapi kalau diwarnai dengan fitnah, korban bisa lebih banyak dan lebih luas. Akibat fitnah, teman sendiri atau keluarga kita bisa terbunuh dan masukpenjara, padahal dia tidak melakukan perbuatan yang dituduhkan.

Tontonan yang menuntun kepada ghibah dan fitnah lambat laun akan merecoki pemikiran masyarakat. Infotainment yang berisi ghibah dan fitnah menggiring secara serentak menuju masyarakat yang hobi membicarakan hal-hal negatif. Akhirnya, perbuatan yang dalam ajaran agama dikutuk itu dianggap perbuatan biasa yang justru sering diperbincangkan di lingkungan keluarga dan lingkungan pendidikan lainnya.

\section{Nilai Keadaban}

Para pengusaha media elektronik yang memiliki tayangan infotainment harus memperhatikan nilai-nilai keadaban, etika moral dan estetika publik. Tak boleh seenaknya mereka menyajikan berita perceraian, skandal seks, hamil di luar nikah, pertengkaran antar anggota keluarga di kalangan artis atau tokoh terkenal lainnya, kalau belum terbukti kebenarannya. Kalaupun terbukti kebenarannya, haruslah disampaikan bila terpaksa secara bijak, kreatif, inovatif dan inspiratif, sehingga tidak membuat desasdesus tak mutu dikalangan luas.

Masyarakat kita membutuhkan tayangan yang bukan hanya menghibur, tapi juga bersifat edukatif. Boleh saja memberitakan soal-soal yang berbau provokatif asal untuk tujuan memperingatkan pihak-pihak yang dianggap menyimpang dari tatanan agama. Infotaiment yang sehat bukan hanya menyajikan berita, tapi harusnya pula ia dilengkapi dengan nasehat-nasehat bijak dan arif.

Di muat Majalah Smart Volume. 1 no. 2 Juli-Desember 2010,

Balai Penelitian dan Pengembangan Agama Semarang 